\title{
Tear production, intraocular pressure and conjunctival microbiota, cytology and histology of New Zealand rabbits (Oryctolagus cuniculus) $^{1}$
}

\begin{abstract}
Arianne P. Oriá ${ }^{2 *}$, Deusdete C. Gomes Junior ${ }^{3}$, Elane A. Arraes ${ }^{4}$, Alessandra Estrela-Lima ${ }^{2}$, Melissa H. Pinna ${ }^{2}$, Íris D.S. Meneses ${ }^{4}$ and Emanoel F. Martins Filho ${ }^{5}$

ABSTRACT.- Oriá A.P., Gomes Junior D.C., Arraes A.E., Estrela-Lima A., Pinna M.H., Meneses I.D.S. \& Martins Filho E.F. 2014. Tear production, intraocular pressure and conjunctival microbiota, cytology and histology of New Zealand rabbits (Oryctolagus cuniculus). Pesquisa Veterinária Brasileira 34(10):1024-1028. Setor de Clínica Médica Veterinária, Escola de Medicina Veterinária e Zootecnia, Universidade Federal da Bahia, Av. Adhemar de Barros 500, Ondina, Salvador, BA 40170-110, Brazil. E-mail: arianneoria@ufba.br

The purpose of this study was to establish reference values for selected ophthalmic diagnostic tests in New Zealand rabbits (Oryctolagus cuniculus). A total of 22 adult male rabbits were used. The ophthalmic tests included evaluation of tear production with Schirmer tear test 1(STT1) and Endodontic absorbent paper point tear test (EAPPTT) using two different commercial brand materials. Applanation tonometry, Culture of the conjunctival bacterial flora, , conjunctival cytology and conjunctival histology were also performed. Mean $( \pm$ SD) for STT1, EAPPTTa, EAPPTTb and IOP was $7.27 \pm 2.51 \mathrm{~mm} / \mathrm{min}, 12.43 \pm 1.69 \mathrm{~mm} / \mathrm{min}$, $15.24 \pm 2.07 \mathrm{~mm} / \mathrm{min}, 12.89 \pm 2.80 \mathrm{~mm} \mathrm{Hg}$, respectively. Staphylococcus epidermidis, Staphylococcus sp. and Bacillus sp. were predominant. The cytological evaluation revealed the presence columnar epithelial cells, superficial squamous keratinized cells, lymphocytes, heterophils, red blood cells, mucus and bacteria. The histological analysis revealed a stratified epithelium, characterized by the presence of columnar epithelial cells with a large number of goblet cells. The reported data can be used for therapeutic or experimental purposes.
\end{abstract}

INDEX TERMS: Tear production, intraocular pressure, conjunctival microbiota, New Zealand rabbits, Oryctolagus cuniculus, lagomorphs, ophthalmology, Schirmer tear test, tonometry, endodontic paper point.

RESUMO.- [Produção lacrimal, pressão intraocular, microbiota, citologia e histologia conjuntival de coelhos Nova Zelândia.] 0 objetivo deste estudo foi estabelecer va-

\footnotetext{
${ }^{1}$ Received on January 24, 2014.

Accepted for publication on August 18, 2014.

${ }^{2}$ Departamento de Anatomia, Patologia e Clínicas, Escola de Medicina Veterinária e Zootecnia, Universidade Federal da Bahia (UFBA), Av. Adhemar de Barros s/n, Salvador, BA 40170-110, Brazil. *Corresponding author: arianneoria@ufba.br

${ }^{3}$ Programa de Pós-Graduação em Ciência Animal nos Trópicos, Escola de Medicina Veterinária e Zootecnia, UFBA, Salvador, BA.

${ }^{4}$ Médica Veterinária autônoma, Rua Jayme Sapolnik 1183, Torre B, Apto 905, Imbuí, Salvador, BA 41720-075.

${ }^{5}$ Programa de Pós-Graduação em Cirurgia Veterinária, Faculdade de Ciências Agrárias e Veterinárias, Universidade Estadual Paulista (Unesp), Via de Acesso Prof. Paulo Donato Castellane s/n, Jaboticabal, SP 14884900, Brazil.
}

lores de referência para testes diagnósticos oftálmicos em coelhos da raça Nova Zelândia (Oryctolagus cuniculus). 22 coelhos, machos, adultos foram utilizados. Foi mensurada a produção lacrimal através do teste lacrimal de Shirmer 1 (TLS1) e da Tira endodôntica de papel absorvente (EAPPTT) de duas marcas comerciais distintas. Tonometria de aplanação, identificação da microbiota conjuntival, , citologia e histologia conjuntival também foram realizadas. A média e desvio padrão do TLS1, EAPPTT1, EAPPTT2 e pressão intraocular foi $7,27 \pm 2,51 \mathrm{~mm} / \mathrm{min}, 12,43 \pm 1,69$ $\mathrm{mm} / \mathrm{min}, 15,24 \pm 2,07 \mathrm{~mm} / \mathrm{min}$ e $12,89 \pm 2,80 \mathrm{mmHg}$, respectivamente. Staphylococcus epidermidis, Staphylococcus sp. e Bacillus sp. mostraram-se predominantes. A citologia conjuntival evidenciou a presença de células epiteliais colunares, células escamosas superficiais queratinizadas, linfócitos, heterofilos, células sanguíneas, muco e bactérias. A 
histologia revelou epitélio estratificado caracterizado pela presença de células epiteliais colunares com grande número de células caliciformes. Os achados deste estudo poderão ser utilizados com fins terapêuticos ou experimentais.

TERMOS DE INDEXAÇÃO: Produção lacrimal, pressão intraocular, coelhos Nova Zelândia, Oryctolagus cuniculus, lagomorfos, oftalmologia, teste lacrimal de Schirmer, tonometria, tira endodôntica de papel absorvente

\section{INTRODUCTION}

The domestic rabbit (Oryctolagus cuniculus) has been commonly used on scientific research (Wagner and Fehr 2007). In the field of experimental ophthalmology they are used in tests of new medication, surgical procedures and compatibility of biomaterials to be used in humans (Oriá et al. 2006, Werner et al. 2006, Kowalski et al. 2012).

Reports of glaucoma in rabbits date back to 1963 when Kolker et al. reported that Glaucoma occurred spontaneously. Kneeper et al. (1978) reported that glaucoma could be induced by corticosteroids. This has been investigated and proven that young animals show a greater predisposition (Yi et al. 2012). For several years rabbits have been used in experimental studies for treatment of human glaucoma. Furthermore, when raised as domestic animals, they occasionally present eye disorders that need clinical or surgical treatment (Keller et al. 2007, Florin et al. 2009) due to occurrence of cataract, conjunctivitis, keratitis, eyelid laceration and dacryocystitis (Jeong et al. 2005).

Thereby, the study's objective was to evaluate the ophthalmic parameters in clinically healthy adult rabbits, aiming to establish standards to be used on an experimental or therapeutic basis.

\section{MATERIALS AND METHODS}

Twenty-two healthy New Zealand 1 to 2-year-old male rabbits (Oryctolagus cuniculus), weighing 2.5 to $3.3 \mathrm{~kg}$, obtained from the Sector of Rabbit Breeding, Recôncavo Federal University, Bahia, were used in this investigation.

The research protocols were approved by the Ethics Committee of the School of Veterinary Medicine and Zootechny of the Federal University of Bahia. The bioethical guidelines of the Association for Research in Vision and Ophthalmology (National Institutes of Health, Publication No. 85-23: Revised, 1985) for the use of animals in vision research were followed.

The rabbits were kept in a bioterium in individual cages during the entire study period with water and appropriate diet ad libitum. After collection of the ophthalmic data a complete physical examination was performed and the anterior ocular structures of all rabbits were evaluated using a transilluminator, a binocular magnifying loupe $(3 \mathrm{x})$ and fluorescein dye $\left(0\right.$ phthalmos ${ }^{\circledR}$, Ribeirão Preto, São Paulo, Brazil). All ophthalmic data was collected by the same investigator (AO) with the exception of Endodontic absorbent paper point tear test (EAPPTT), conducted by (DCGJ). All tests were performed between 8-10am and only gentle physical restraint was used to immobilize the animals for data acquisition. Special attention was paid to avoid applying any pressure in the neck region in order to prevent iatrogenic IOP alterations.

Data was collected from two groups. In group $1(n=12)$, STT1, sampling of conjunctival bacterial flora, tonometry, conjunctival cytology and conjunctival histology were performed. In group 2 $(\mathrm{n}=10)$, EAPPTT was conducted.
STT1 standardized strips (Ophthalmos ${ }^{\circledR}$, Ribeirão Preto, São Paulo, Brazil) were used to measure the aqueous tear film component in both eyes of 12 rabbits. The strips were placed in the lower conjunctival fornix of each eye for 60 seconds using sterile gloves and without installation of topical anesthesia, to avoid confounding the results of the subsequent bacterial sampling. No other eye procedure was performed prior to STT1 in these animals.

Swabs of sterile hydrophilic cotton were pressed and retained directly and lightly against the lower conjunctival fornix of both eyes of the same 12 animals. Swabs were immediately sent in triptose agar medium to the Bacterioses Laboratory, Veterinary Hospital, Federal University of Bahia. Culturing of the microorganisms was performed in Petri dishes with sheep blood agar to $6 \%$ MacConkey agar and tryptose broth, which were incubated at $37^{\circ} \mathrm{C}$ in an aerobic environment for 24 to $48 \mathrm{~h}$. After growth, the colonies were identified based on the presence or absence of hemolysis on blood agar and morphological and biochemical characteristics according to routine laboratory techniques. Yeasts were not surveyed in this study.

Before measurements, one drop of proxymetacaine (Anestalcon ${ }^{\circledR}$, Alcon, São Paulo, São Paulo, Brazil) was instilled in each eye. IOP was measured in both eyes of the same 12 rabbits using an applanation tonometer (TonoPen ${ }^{\circledR} \mathrm{XL}$, Reichert Technologies, Depew, New York, USA). Immediately after tonometry, samples of conjunctival cytology were collected bilaterally from 10 rabbits of Group 1, yielding a total of 20 samples. A barren interdental brush (conic interdental brush $\mathrm{B}^{\circledR}$, Procter \& Gamble do Brazil, Manaus, Amazonas, Brazil) was used to collect cytology samples from the left conjunctival fornix, and a sterile cotton swab previously moistened with sterile saline solution was used to collect cytology samples from the right fornix, using smooth rotational movements. Samples were distributed onto glass slides, air dried and stained using the Panoptic fast method. Microscopic evaluation of the slides was done using 1000x of magnification, while paying special attention to characterizing the exfoliated cell populations. Cell concentration was semi-quantified using the following scale: very low numbers (rare), a small number $(+)$, a moderate number $(++)$ and a large number $(+++)$ of cells. Additionally, cell integrity and the likelihood of iatrogenic tissue injury (based on the presence of intact erythrocytes) were evaluated.

The dorsal bulbar conjunctiva of both eyes of the same 10 rabbits was gently lifted with Adson forceps. A $5 \mathrm{~mm}$ sample was cut using iris scissors. The samples were immerged in a $10 \%$ buffered formalin solution, processed routinely for histopathology and stained with Haematoxylin and Eosin (HE) at the Laboratory of Veterinary Pathology, Veterinary Hospital, Federal University of Bahia.

Endodontic absorbent paper point strips, $28 \mathrm{~mm}$ in length, from two different commercial brands were used. EAPPTT ${ }^{\mathrm{a}}$ and EAPPTT $^{\mathrm{b}}$ were conducted using Dentsply (Color size 30, Rio de Janeiro, Brazil) and Roeko color (Color size 30, Langenau, Germany) strips respectively. The strip was placed in the lower conjunctival fornix of each eye of 10 rabbits (Group 2) and held in place for one minute (Fig.1). The moistened amount of the strip was measured with the aid of a digital caliper (Mitutoyo, São Paulo, São Paulo, Brazil), immediately after its removal.

The Shapiro-Wilk test was used to test data normality of qualitative variables (STT1, IOP, EAPPTT ${ }^{\mathrm{a}}$ and EAPPTT ${ }^{\mathrm{b}}$ ). Differences between mean values of variables were tested using paired Student's t-tests and the correlation between quantitative tear production variables was evaluated using the Pearson correlation test. All analysis was performed using SPSS (IBM Corp Releases 2011. IBM SPSS Statistics for Windows, Version 20.0. Armonk, NY: IBM Corp.) and differences were deemed significant when $P<0.05$. 


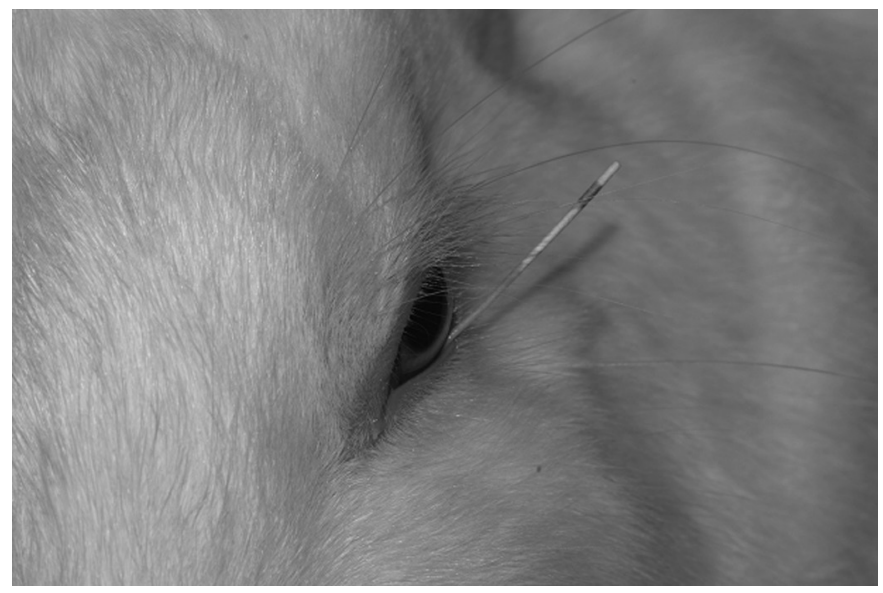

Fig.1. Measurement of tear production with the Endodontic absorbent paper point Roeko color (Color size 30, Langenau, Germany).

\section{RESULTS}

The data collected for STT, EAPPTT ${ }^{\mathrm{a}}$, EAPPTT ${ }^{\mathrm{b}}$ and IOP was normally distributed, based on the Shapiro-Wilk normality test ( $\mathrm{p}=0.162,0.819,0.819$ and 0.274 respectively). Descriptive statistics of the results of these tests are presented in Table 1.

There were no significant differences between left and right eyes for STT $(p=0,208)$, EAPPTT $(p=0,986)$, EAPPT$\mathrm{T}^{\mathrm{b}}(\mathrm{p}=0,816)$ and IOP $(\mathrm{p}=0,793)$ (Paired Student t-tests) and there was no significant correlation between EAPPTT ${ }^{a}$ and EAPPTT ${ }^{\mathrm{b}}$ using Pearson's correlation test $(\mathrm{p}=0,172 \mathrm{r}=$ $-0,475)$.

A total of 8 types of Gram-positive bacteria and 1 type of Gram-negative bacteria were isolated and are presented in Table 2. In 83.3\% (10/12) of animals, both eyes yielded positive culture results; $16.7 \%(2 / 12)$ of anmals yielded positive culture in one eye.

Macroscopically, no conjunctival trauma was observed with either sampling method. Columnar epithelial cells, superficial squamous keratinized cells, lymphocytes, heterophils and red blood cells were the main cell populations observed (Fig.2). Bacteria and mucus filaments were also observed. Slides obtained using a barren interdental brush showed greater cellularity than those obtained with the moistened cotton swab (Fig.3).

Histology of the conjunctiva revealed stratified epithelium, characterized by the presence of layers of columnar epithelial cells. Large numbers of goblet cells were obser-
Table 1. Results of select ophthalmic diagnostic tests in the Oryctolagus cuniculus eye

\begin{tabular}{lcccc}
\hline Variable & $\mathrm{n}$ & $\begin{array}{c}\text { Mean } \\
\text { Value }\end{array}$ & $\begin{array}{c}\text { Standard } \\
\text { Derivation }\end{array}$ & $\begin{array}{c}95 \% \text { Confidence } \\
\text { Interval }\end{array}$ \\
\hline STT $(\mathrm{mm} / \mathrm{min})$ & 11 & 7.27 & 2.51 & $6.16-8.38$ \\
EAPPTT $^{\mathrm{a}}(\mathrm{mm} / \mathrm{min})$ & 10 & 12.43 & 1.69 & $11.64-13.22$ \\
EAPPTT $^{\mathrm{b}}(\mathrm{mm} / \mathrm{min})$ & 10 & 15.24 & 2.07 & $14.27-16.21$ \\
IOP $(\mathrm{mm} / \mathrm{Hg})^{12}$ & 12.89 & 2.80 & $11.71-14.07$
\end{tabular}

$\overline{\text { ST }}=$ Schirmer tear test $1 ;$ EAPPTT $^{\mathrm{a}}=$ Endodontic absorbent paper point $^{2}$ tear testa; EAPPTT $^{\mathrm{b}}$ = Endodontic absorbent paper point tear testb; IOP $=$ Intraocular pressure.

Table 2. Bacteria isolated from the conjunctival sac of healthy adult Oryctolagus cuniculus

\begin{tabular}{llc}
\hline Bacteria & & Total (\%) \\
\hline Gram- & Diphtheroids & $3(9.1)$ \\
Gram+ & Bacillus sp. & $7(21.3)$ \\
& Staphylococcus sp. & $8(24.2)$ \\
& Staphylococcus epidermidis & $8(24.2)$ \\
& Micrococcus sp. & $1(3.0)$ \\
& Streptococcus spp. & $1(3.0)$ \\
& Staphylococcus intermedius & $1(3.0)$ \\
Total & Streptococcus $\beta$-hemolitico & $2(6.1)$ \\
Gram-Negative & Enterobacter sp. & $31(93.9)$ \\
Total & & $2(6.1)$ \\
GRAND TOTAL & & $2(6.1)$ \\
& & $33(100)$
\end{tabular}

ved in the epithelium. A vascularized lamina propria formed by loose conjunctival tissue was observed and clusters of lymphoid cells were also seen (Fig.4).

\section{DISCUSSION}

Rodents are increasingly seen as pet species and thus the ophthalmic diseases may be presented to veterinarians in general practice (Williams 2007). They are also still considered and used as experimental model in researches (Oriá 2006). In the scientific literature there are scarce information concerning the baseline values for the routine ophthalmic diagnostic tests in rabbits. Besides, there are small but significant anatomical and physiological differences between the eyes of dogs and cats and those of rabbits (Williams 2007). Therefore the study of ophthalmic parameters becomes of great importance and should be considered for different species.

In this study, bacterial growth was identified in $91.7 \%$ of the ocular samples $(22 / 24)$. Similar result was found

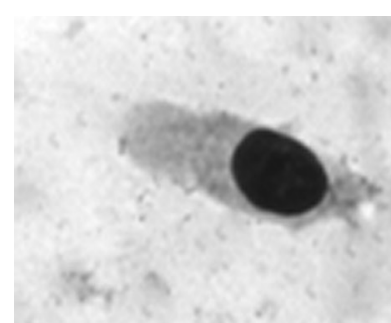

A

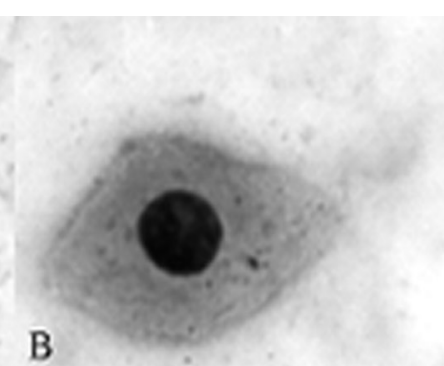

B

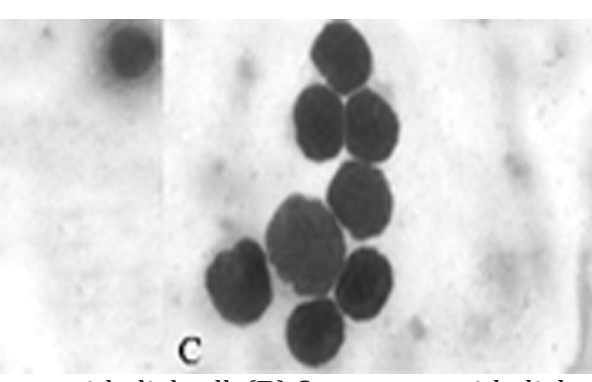

Fig.2. Cell types observed in rabbit samples of conjunctival cytology. (A) Columnar epithelial cell. (B) Squamous epithelial cell (left) and erythrocyte (right). (C) Lymphocytes. Panoptic 1000x. 
by Cooper et al. (2001) (83\%) in assessing the conjunctival microbiota of domestic rabbits. Out of the 33 strains isolated, 93.9\% were Gram positive and 6.1\% were Gram negative (see Table 2). Studies conducted on other species such as dogs $73.23 \%$ (Santos 2009) and $86.2 \%$ (Oliveira 2010); several domestic and wild species with $81 \%$ (Santos 2011) also presented a predominance of Gram positive bacteria.

The Staphylococcus genus had been found on high frequency in rabbits (57\%) by others authors as Cooper et al. (2001); Kudirkienè (2006) in dogs (55\%) and Santos (2011) in several species (46.8\%). According to Shimamura (2008) the microorganisms of this genus are widely distributed in nature, as part of mammals and birds natural microbiota of the skin and mucosa. Haghkhah et al. (2005) and Oliveira et al. (2010) found high frequency for Staphylococcus epidermidis and Bacillus sp. in the conjunctival microbiota of healthy dogs, as observed in this study. According to Belletato (1981) the Staphylococcus epidermidis species is commonly found in the conjunctival fornix. Enterobacter cloacae was the only Gram negative bacteria isolated. According to Spinelli (2010) these microorganisms are present in healthy eyes, however, in small number, as noticed.

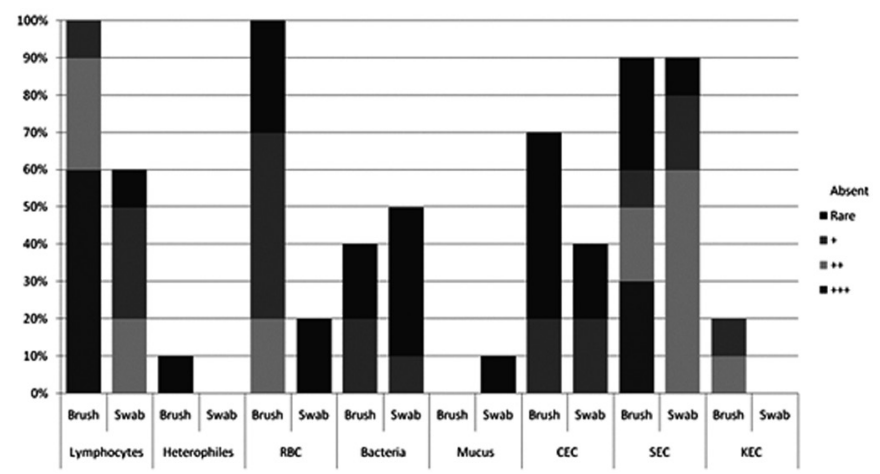

Fig.3. Distribution and quantification of cells observed in conjunctival cytology of New Zealand rabbits (Oryctolagus cuniculus), comparing two collection techniques (brush and swab). Red blood cells (RBC), columnar epithelial cells (CEC), squamous epithelial cells (SEC), and keratinized epithelial cells (KEC). Discrete presence (rare), small amount $(+)$, moderate amount $(++)$ and a large amount $(+++)$.
The STT1 has a low cost, is easy to perform and is also used to confirm CCS (low values) or to correlate with signs of irritation (high values) in veterinary practice. CCS naturally acquired has not been reported in rabbits; therefore, STT1 in rabbits has greater utility in the second case (Abrams et al. 1990, Koç et al. 2005).

Koç et al. (2005) determined that the mean value for STT1 in clinically normal rabbits was $8.1 \pm 3.4 \mathrm{~mm} / \mathrm{min}$. The mean values for STT1 in New Zealand and Angora rabbits breeds and Mixed breed rabbits were of 7.9 $\pm 3.6,7.2 \pm 2.9$ and $9.1 \pm 3.3 \mathrm{~mm} / \mathrm{min}$, respectively. These data are similar to those found in this study $(7.3 \pm 2.5 \mathrm{~mm} / \mathrm{min})$, however, inferior results were described by Abrams et al. (1990) $(5.30 \pm 2.96 \mathrm{~mm} / \mathrm{min})$.

EAPPTT is widely used in dentistry during endodontic procedures, due to its high absorption properties. However its use in measuring the aqueous component of the tear film is not yet wide-spread (Lange et al. 2012). Relatively to its use, the EAPPTT revealed a greater insertion into the conjunctival fornix and produced smaller discomfort for the animal when compared to STT1. It was easy to use, and the strip was readily inserted by one person. There was small disperse of values in the comparison of the two brands of EAPPTT, however, it is noteworthy that the value from the tear production measurement with one of the brands can't be compared to the values of the other one, once there is no overlap of the confidence interval. There are some possible explanations for this variance in the results concerning the two brands and these include the differences in the strips raw materials and its absorbance properties.

The mean IOP obtained in healthy adults rabbits with the rebound tonometer -Tonovet was $10.2 \pm 1.3 \mathrm{mmHg}$ (Albuquerque et al. 2008) and $9.5 \pm 2.6 \mathrm{mmHg}$ (Pereira 2010) and with the Tono-Pen Avia was $15.4 \pm 2.2 \mathrm{mmHg}$ (Pereira 2010). The values obtained in this study suggest that the IOP with the Tono-Pen XL presents intermediate values between the two other types of tonometers tested.

Relative to the collection methods, the samples obtained with the barren interdental brush presented superior number of cells and cellular diversity compared to the ones obtained with moisturized cotton swabs, as remarked by other studies (Willis et al. 1997, Borges 2012). Similarly the samples obtained by swab presented higher frequency in collecting mucus and bacteria concerning the ones taken

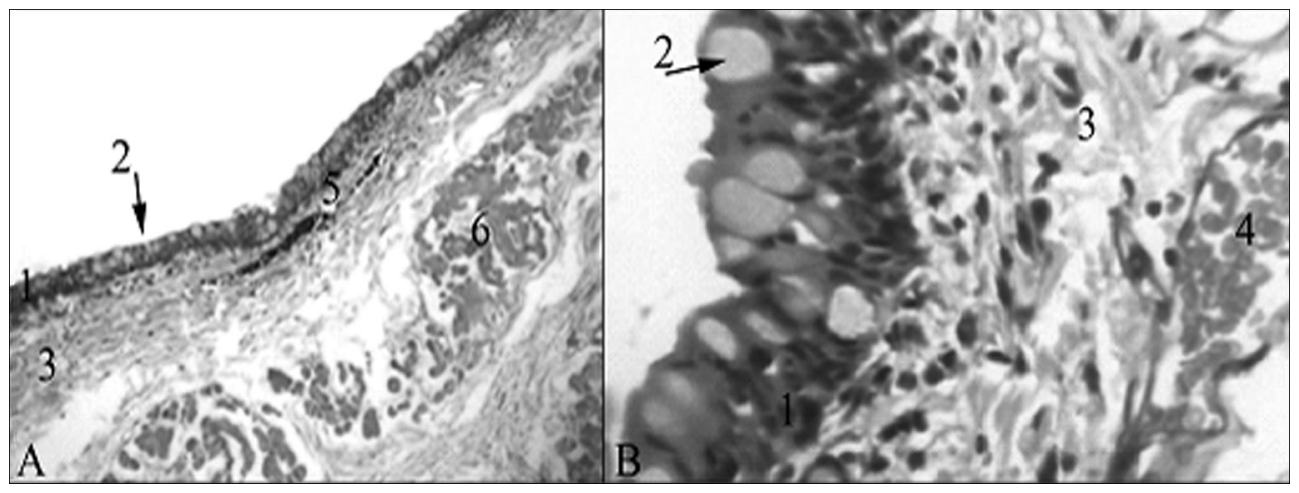

Fig.4. (A,B) Histological evaluation of the rabbit conjunctiva. Note: Columnar stratified epithelium (1), goblet cells (2), loose conjunctive tissue (3), blood vessel with erythrocytes (4), cluster of lymphoid cells (5), muscular fibers (6). (A) HE, 100x. (B) HE, 400x. 
by brushes, what can be related to the absorption capacity of the cotton.

The normal conjunctival epithelium is characterized by groups of epithelial cells and some individual cells (Rito 2009). The morphologic characteristics of the cells depend on the depth of the cytological collecting, and all cell layers can be found at the same sample. The small amount of keratinized epithelial cells found with the brush method suggests a skin contamination since this cellular type is not present in the conjunctiva. This could be the consequence of the brush's bigger contact surface when compared to the swab during sample collection. Various types of lymphoid cells were found in the conjunctival cytology, however, some authors indicated that, in animals with no clinical signs of conjunctivitis, little emphasis should be given to this cellular type (Bolzan et al. 2005). The presence of intact erythrocytes in samples collected through exfoliation with the brush, suggests that micro vascular lesions could have occurred, but without immediate or late clinical changes as we didn't observe any macroscopic conjunctival trauma or blood on the brush following sampling.

The stratified columnar epithelium is more commonly found in the conjunctival fornix and at the eyelid margin (tarsal region) the epithelium becomes stratified squamous as well as at the bulbar conjunctiva (Kuehnel 2003). This explains the obtainment of squamous and columnar cells in the conjunctival cytology where the sampling area was the entire conjunctiva compared to histology where the sampling area was the conjunctival fornix.

The columnar non-keratinized stratified epithelium observed in the rabbit's conjunctiva was similar to the histological description of dogs (Samuelson 2007) and horses (Aughey \& Frye 2001). The lamina propria, located in the subepithelial tissue, comprises a highly vascularized loose connective tissue, where clusters of lymphoid cells can be found (Samuelson 2007), as observed in this study.

\section{CONCLUSION}

The values found in this study can guide veterinarians that work with leporines, either for therapeutic or experimental purposes.

\section{REFERENCES}

Abrams K.L., Brooks D.E., Funk R.S. \& Theran P. 1990. Evaluation of the Schirmer tear test in clinically normal rabbits. Am. J. Vet. Res. 51:19121913.

Albuquerque L., Almeida A.C.V.R., Faganello C.S., Casarin C.D., Pereira F.Q. \& Pigatto J.A.T. 2008. Mensuração da pressão intra-ocular em coelhos saudáveis utilizando o tonômetro de rebote (Tonovet ${ }^{\circledR}$ ). Proceedings 35 Congresso Brasileiro de Medicina Veterinária, Gramado, RS, p.811.

Belletato A. \& Centelhas A.C. 1981. Investigação clínico-laboratorial das conjuntivites bacterianas. Arqs Médicos do ABC 4.

Bolzan A.A., Brunelli A.T.J., Castro M.B., Souza M.A., Souza J.L. \& Laus J.L. 2005. Conjunctival impression cytology in dogs. Vet, Ophthalmol. 8:401405

Borges R.F., Cardoso K.C.F., Bolzan A.A., Momo C. \& Honsho C.S. 2012. Estudo comparativo de métodos de coleta e coloração para citologia conjuntival em cães normais. Vet. Zootec., Botucatu, 19:381-391.

Cooper S.C., McLellan G.J. \& Rycroft A.N. 2001. Conjunctival flora ob- served in 70 healthy domestic rabbits (Oryctolagus cuniculus). Vet. Rec. 149:232-235.

Florin M., Rusanen E., Haessig H., Richter M. \& Spiess B.M. 2009. Clinical presentation, treatment, and outcome of dacryocystitis in rabbits: a retrospective study of 28 cases (2003-2007). Vet. Ophthalmol. 12:350-356.

Haghkhah M., Sarchahi A.A. \& Molazem M. 2005. Conjunctival flora in normal dogs. Onderstepoort J. Vet. Res. 9:78-83.

Kdirkiene E., Zilinskas H. \& Siugzdaite J. 2006. Microbial flora of the dog eyes. Veterinarijair Zootechnika 34.

Keller R.L., Hendrix D.V. H. \& Greenacre C. 2007. Shope fibroma vírus keratitis and spontaneous cataracts in a domestic rabbit. Vet. Ophthalmol. 10:190-195

Koç Y., Alkan F. \& Tepeli C. 2005. Schirmer tear test in different rabbit breeds. Hayvanchk Araştirma Dergisi 15:1-5.

Kowalski R.P., Romanowski E.G., Shanks R.M.Q. \& Mah F.S. 2012. The comparison of fluoroquinolones to nonfluoroquinolone antibacterial agents for the prevention of endophthalmitis in a rabbit model. J. Ocular Pharmacol. Therapeut. 28:604-608.

Lange R.R., Lima L. \& Montiani Ferreira F. 2012. Measurement of tear production in black-tufted marmosets (Callithrix penicillata) using three different methods: modified Schirmer's I, phenol red thread and standardized endodontic absorbent paper points. Vet. Ophthalmol. 15:1-7.

Oliveira P.M., Pinna M.H., Oriá A.P., Martins Filho E.F., Laborda S.S., Pithon P.S.B., Gomes Junior D.C. \& Costa Neto J.M. 2010. Polivinilpirrolidona-iodo (PVP-I) em base aquosa na antissepsia de campo operatório oftálmico de cães. Revta Bras. Saúde Prod. Anim. 11:1095-1104.

Oriá A.P., Neto F.A., Laus J.L., Dos Santos L.A., Piza E.T., Brunelli A.T., Nishimori C.T. \& Souza A.L. 2006. Evaluation of a double-setting alfa-tricalcium phosphate cement in eviscerated rabbit eyes. Ophthalmic Plastic and Reconstrutive Surgery 22:126-130.

Pereira F.Q. 2010. Comparação entre o tonômetro de rebote (Tonovet) e o novo tonômetro de aplanação (Tono-pen AVIA) durante curva diurna da pressão intraocular de coelhos adultos. Dissertação de Mestrado, Universidade Federal do Rio Grande do Sul, Porto Alegre, RS. 57p.

Rito I.Q.S. 2009. Utilização da citologia conjuntival no diagnóstico de doenças oculares. Dissertação de Mestrado, Universidade Técnica de Lisboa, Lisboa. 100p.

Samuelson D.A. 2007. Ophthalmic Anatomy, p.37-148. In: Gellat K.N. (Ed.), Veterinary Ophthalmology. $4^{\text {th }}$ ed. Blackwell Publishing, Oxford, UK. $1672 p$.

Santos L.G.F., Almeida A.B.P.F., Silva M.C., Oliveira J.T., Dutra V. \& Sousa V.R.F. 2009. Microbiota conjuntival de cães hígidos e com afecções oftálmicas. Acta Scient. Vet. 37:165-169.

Santos L.L. 2011. Características da microbiota da superfície ocular bacteriana em animais domésticos e silvestres. Dissertação de Mestrado, Universidade Federal do Paraná, Curitiba, PR. 71p.

Shimamura G.M. 2008. Estudo da microbiota conjuntival de cães portadores de Diabetes mellitus. Dissertação de Mestrado, Universidade de São Paulo, São Paulo/SP. 64p.

Spinelli T.P., Oliveira Filho E.F., Silva D., Mota R. \& Sá F.B. 2010. Normal aerobic bacterial conjunctival flora in the Crab-eating raccoon (Procyon cancrivorus) and Coati (Nasua nasua) housed in captivity in Pernambuco and Paraiba (Northeast, Brazil). Vet. Ophthalmol. 13:134-136.

Wagner F. \& Fehr M. 2007. Common ophthalmic problems in pet rabbits. J. Exotic Pet Med. 16:158-167.

Werner L., Chew J. \& Mamalis N. 2006. Experimental evaluation of ophthalmic devices and solutions using rabbit models. Vet. Ophthalmol. 9:281-291.

Williams D. 2007. Rabbit and rodent ophthalmology. Eur. J. Companion Anim. Pract. 3:242-252.

Willis M., Bounous D.I., Hirsh S., Kaswan R., Stiles J. \& Martin C. 1997. Conjunctival brush cytology: evaluation of a new cytological collection technique in dogs and cats with a comparison to conjunctival scraping. Vet. Comp. Ophthalmol. 7:74-81. 